\title{
André Sant'Anna
}

\section{Como você pensa a relação entre o tempo literá-} rio e o tempo histórico?

O tempo histórico é cronológico, é uma fabricação humana para organizar as coisas. Mas o tempo só existe quando relativo ao espaço. Como na literatura não há espaços, podemos abolir o tempo e brincar com uma cronologia anárquica.

Quais procedimentos sua obra adota diante de um mundo em que predominam a ação econômica e a espetacularização da arte?

A minha obra não tem nada a ver com dinheiro, nem com qualquer tipo de espetacularização. Aliás, literatura de qualidade é quase invisível ao que chamamos de "público consumidor" Mas, claro, estou sempre pegando no pé do dinheiro, da celebridade.

\section{Qual reflexão sua obra produz sobre a tradição} literária brasileira?

A tradição literária brasileira não me interessa. Gosto de alguns poucos escritores, que, claro, estão sempre influenciando o que escrevo.

\section{Como você pensa a forma literária?}

Como música. Tento sempre colocar um ritmo, uma harmonia e uma melodia diferentes nas coisas que escrevo. Como o pensamento e as emoções não vêm em forma de palavras escritas, tento encontrar a forma que melhor traduz esses pensamentos e emoções.

André Sant'Anna (1964) é músico, escritor, roteirista de cinema, televisão e publicidade. Formou o grupo performático Tao e Qual, na década de 1980, e atua no espetáculo Satyros Sons e Furyas. É autor de Amor (Edições Dubolso, 1998), Sexo (7 Letras, 1999; Cotovia/ Portugal, 2000), O paraiso ébem bacana (Companhia das Letras, 2006) e Sexo e amizade (Companhia das Letras, 2007). 